\title{
Responding to: Coping with Stress among Androgynous, and Sextyped Persons
}

\author{
Souad Mousa Ahmed Bakhet \\ School of Psychology, Ahfad University Women, Omdurman, Sudan \\ Email: Suoadm.osmanh@gmail.com
}

How to cite this paper: Bakhet, S.M.A. (2021) Responding to: Coping with Stress among Androgynous, and Sextyped Persons. Open Access Library Journal, 8: e7734. https://doi.org/10.4236/oalib.1107734

Received: July 5, 2021

Accepted: August 13, 2021

Published: August 16, 2021

Copyright $\odot 2021$ by author(s) and Open Access Library Inc.

This work is licensed under the Creative Commons Attribution International License (CC BY 4.0).

http://creativecommons.org/licenses/by/4.0/

\section{(c) (i) Open Access}

\begin{abstract}
Aim: The aim of this study is identify the role of traditional sextyped and androgynous individual in responding to and coping with stress and suggest type of preventive socializing procedure that considers psychological androgyny, and to contribute to the knowledge pertaining to the area of sextyped and mental health in Sudan. Methods: A questionnaire consists of three parts, Bem sex role inventory, the social readjustment rating scale and some of the psychosomatic diseases distributed to 155 secondary school teachers (77 males and 78 females). Results: Males and females were equal in androgynous sextyped. The traditionally sextype females represent $60.3 \%$ while traditionally sextyped males are $29.9 \%$. The biographical data significantly correlated with responding to and coping with stress (negative and positive correlation). Sextyped correlated positively with urban and rural childhood dichotomy. Conclusion: Feminine sextyped and androgynous persons respond positively to stress, in accordance they cope directly to eliminate it psychosomatic diseases prevail more among feminine sextyped (42.9\%) and androgynous, 31.9\%).
\end{abstract}

\section{Subject Areas}

Psychology

\section{Keywords}

Androgynous, Sextyped (Feminine Masculine), Responding to Stress and Coping Strategies

\section{Introduction}

In Sudan, there were huge changes that occurred since independence, there were many studies concerned with these changes in various aspects, including eco- 
nomic, social, political, legal, environmental and demographic. There is a gap between the rate of development of men and that of woman in terms of education, work and family positions. Moreover, a lot of effort had done to fill in this gap. Most of these studies involve a description and evaluation of the position of women compared to men.

Sudan is a developing nation that faces many challenges concerning gender inequality. Freedom House gave Sudan the lowest possible ranking among repressive regimes during 2012. South Sudan received a slightly higher rating but it also rated as "not free". In the 2013 report of 2012 data, Sudan ranks 171st out of 186 countries on the Human Development Index (HDI). Stress is a particular pattern of disturbing psychological, physiological reactions that occur when environmental events threaten important needs, motivates, and put strain on the ability to cope. The concept of androgyny has become the hallmark of contemporary mental health. The androgynous individuals described as flexible, adaptive, adjusted and liberated [1]. Stress as a phenomenon threatens the mental health and wellbeing of individuals. Thus, coping with stress and means of adaptation depend on many factors such as age, gender, socioeconomic status, and the nature of the stressors. The objectives of this study are to identifying the role of sextype (male/female, androgynous, and undifferentiated) traits in facing some of stressful life events, and its coping strategies among secondary school teachers, gender norms, roles and relations influence people's susceptibility to different health conditions and diseases and affect their enjoyment of good mental, physical health and wellbeing. They also have a bearing on people's access to and uptake of health services and on the health outcomes, they experience throughout the life-course. Most people experience stress as negative, i.e. the associated feelings, thoughts, body sensations and behaviors perceived negatively. Several feelings that people associate with stress, either as a result or cause, are anger, insecurity, sadness, weakness, anger, bitterness among others.

\section{Material and Methods}

The principal tool used was a questionnaire. It consists of three parts, Bem sex role inventory for measuring androgyny is the most commonly used and validated gender role measurement tool across countries and age groups. However, it rarely validated in older adults and sporadically used in aging and health studies. Perceived gender role is a crucial part of a person's identity and an established determinant of health [2]. The social readjustment rating scale for stress measure [3] Results indicated a highly rigid structure of three factors corresponding to social competence. Cronbach's alpha coefficients ranged from 0.91 to 0.93 across the sampled age groups. The SSS is able to measure social competence with high validity and reliability, and some of the psychosomatic diseases.

\section{Results}

Factor analysis, correlation coefficient, chi-square, and disease may indicate an 
indirect coping strategy. Multiple regression applied in analyzing the data. General hypotheses for the study that were androgynous person respond to and cope with stress positively and directly. As age increases the responding to and coping with stress become less positive and less direct, psychosomatic.

Table 1 showed that correlation between demographic information of the respondent and their sextyped with responding to stress.

Table 2 showed the correlation between demographic variables of the respondents and their sextype with coping with stress.

Table 3 shows that there are significant differences concerning gender across the 4 categories of sextyped $\left(\mathrm{x}^{2}=42.90, \mathrm{df}=3, \mathrm{P}<0.001\right)$.

It can be seen from this Table 4 that there is significant age differences across the four categories of sextyped $\left(\mathrm{x}^{2}=16.23, \mathrm{df}=6, \mathrm{P}<0.01\right)$. This means that androgynous model adopted more among the young age groups. It is a modern orientation and usually the young people like to adopt a modern thing.

In other words, the young i.e. 30 through 39 years represents $86.9 \%$.

Table 1. General correlation between biographical variables and responding to stress.

\begin{tabular}{|c|c|c|c|c|c|c|c|c|c|c|c|}
\hline $\begin{array}{l}\text { Responding to } \\
\text { Stress } \\
\text { Biographical } \\
\text { data }\end{array}$ & $\begin{array}{l}\text { Sex } \\
\text { type }\end{array}$ & $\begin{array}{l}\text { Death } \\
\text { of } \\
\text { spouse }\end{array}$ & $\begin{array}{l}\text { Response } \\
\text { to divorce }\end{array}$ & $\begin{array}{l}\text { Response } \\
\text { to death of } \\
\text { relative }\end{array}$ & $\begin{array}{l}\text { Response } \\
\text { to } \\
\text { marriage }\end{array}$ & $\begin{array}{l}\text { Response } \\
\text { to } \\
\text { pregnancy }\end{array}$ & $\begin{array}{l}\text { Response } \\
\text { to } \\
\text { retirement }\end{array}$ & $\begin{array}{l}\text { Response to } \\
\text { sex } \\
\text { difficulties }\end{array}$ & $\begin{array}{l}\text { Response } \\
\text { to death of } \\
\text { friend }\end{array}$ & $\begin{array}{l}\text { Response } \\
\text { to habit } \\
\text { change }\end{array}$ & $\begin{array}{l}\text { Response to } \\
\text { change in } \\
\text { responsibility }\end{array}$ \\
\hline Gender & & & & & & $* *$ & & & & $* *$ & $* *$ \\
\hline (Male/Female) & & & & & & 0.37 & & & & 0.26 & 0.23 \\
\hline \multirow[t]{2}{*}{ Age } & & * & & $* *$ & $* *$ & * & * & * & * & * & \\
\hline & & -0.17 & & 0.20 & 0.28 & 0.16 & 0.18 & -0.19 & -0.16 & 0.18 & \\
\hline \multirow[t]{2}{*}{ Residence } & $* *$ & & & & & * & & & & * & \\
\hline & 0.15 & & & & & -0.22 & & & & -0.17 & \\
\hline Marital & $\star *$ & $* *$ & & & $* *$ & $* *$ & & * & & & \\
\hline status & 0.33 & 0.33 & & & -0.49 & -0.49 & & -0.18 & & & \\
\hline
\end{tabular}

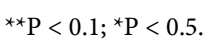

Table 2. General correlation between biographical variables and coping with stress.

\begin{tabular}{|c|c|c|c|c|c|c|c|c|c|c|}
\hline $\begin{array}{ll}\text { Responding to } & \text { Sex } \\
\text { Stress } & \text { type } \\
\text { Biographical } & \\
\text { data } & \end{array}$ & $\begin{array}{l}\text { Death } \\
\text { of } \\
\text { spouse }\end{array}$ & $\begin{array}{l}\text { Response } \\
\text { to divorce }\end{array}$ & $\begin{array}{l}\text { Response } \\
\text { to death } \\
\text { of relative }\end{array}$ & $\begin{array}{l}\text { Response } \\
\text { to } \\
\text { marriage }\end{array}$ & $\begin{array}{l}\text { Response to } \\
\text { pregnancy }\end{array}$ & $\begin{array}{l}\text { Response to } \\
\text { retirement }\end{array}$ & $\begin{array}{l}\text { Response } \\
\text { to sex } \\
\text { difficulties }\end{array}$ & $\begin{array}{l}\text { Response } \\
\text { to death of } \\
\text { friend }\end{array}$ & $\begin{array}{l}\text { Response } \\
\text { to habit } \\
\text { change }\end{array}$ & $\begin{array}{l}\text { Response to } \\
\text { change in } \\
\text { responsibility }\end{array}$ \\
\hline Gender & & & & $* *$ & & & & & & \\
\hline (Male/Female) & & & & 0.37 & & & & & & \\
\hline \multirow[t]{2}{*}{ Age } & & & & $* *$ & $* *$ & & * & & & \\
\hline & & & & 0.36 & 0.18 & & -0.16 & & & \\
\hline \multicolumn{11}{|l|}{ Residence } \\
\hline Marital & $* *$ & & & $* *$ & $* *$ & & & & * & \\
\hline status & 0.37 & & & -0.54 & -0.45 & & & & -0.19 & \\
\hline
\end{tabular}

${ }^{* *} \mathrm{P}<0.01 ;{ }^{*} \mathrm{P}<0.05$. 
Contrary to our hypothesis, the feminine sextyped responded to across positively, followed by androgynous $55 \%$ and $26.6 \%$, respectively while masculine sextype only who responded to stressful positively were $5.9 \%$ (Table 5).

For coping strategies, Table 6 shows the differences among the 4 groups. A significant difference exists in coping with death of a relative, $x^{2}=16.63, \mathrm{df}=9$, $\mathrm{P}<0.05$.

The result in Table 7 shows that, being sextyped in feminine, masculine direction,

Table 3. Sextype by gender.

\begin{tabular}{cccccc}
\hline Groups & No. \% & Masculine Sextype & Feminine Sextype & Androgynous & Near Masculine \\
\hline Male & No & 23 & 13 & 23 & 18 \\
& $\%$ & 29.9 & 16.9 & 29.9 & 23.4 \\
Female & No & 2 & 47 & 23 & 6 \\
& $\%$ & 2.6 & 60.3 & 29.9 & 7.7 \\
\multirow{2}{*}{ Total } & No & 25 & 60 & 46 & 24 \\
& $\%$ & 100.0 & 100.0 & 100.0 & 100.0 \\
\hline
\end{tabular}

Table 4. Sextype by age.

\begin{tabular}{cccccc}
\hline Groups & No. \% & Masculine Sextyped & Feminine Sextyped & Androgynous & Near Masculine \\
\hline 30 less & No & 6 & 33 & 26 & 7 \\
& $\%$ & 8.33 & 45.8 & 36.11 & 9.72 \\
$31-39$ & No & 14 & 23 & 14 & 16 \\
& $\%$ & 20.0 & 34.3 & 20.0 & 23.9 \\
40 more & No & 5 & 4 & 6 & 1 \\
& $\%$ & 31.3 & 25.7 & 37.0 & 4.2 \\
\multirow{2}{*}{ Total } & No & 25 & 60 & 46 & 24 \\
& $\%$ & 100.0 & 100.0 & 100.0 & 100.0 \\
\hline
\end{tabular}

Table 5. Sextyped by response to injury/illness.

\begin{tabular}{cccccc}
\hline Groups & No. $\%$ & Masculine Sextyped & Feminine Sextyped & Androgynous & Near Masculine \\
\hline No & No & 7 & 23 & 17 & 13 \\
Response & $\%$ & 11.7 & 31.3 & 29.3 & 21.7 \\
Always & No & 4 & 19 & 9 & 2 \\
& $\%$ & 11.8 & 55.9 & 26.6 & 5.9 \\
Sometimes & No & 12 & 18 & 20 & 9 \\
& $\%$ & 20.3 & 30.5 & 33.9 & 15.3 \\
Never & No & 2 & 0 & 0 & 0 \\
& $\%$ & 5.9 & 0 & 0 & 0 \\
Total & No & 25 & 60 & 46 & 24 \\
& $\%$ & 100.0 & 100.0 & 100.0 & 100.0 \\
\hline
\end{tabular}


Table 6. Sextyped by coping with death of spouse.

\begin{tabular}{cccccc}
\hline Groups & No. \% & Masculine Sextyped & Feminine Sextyped & Androgynous & Near Masculine \\
\hline No. Coping & No & 7 & 19 & 12 & 10 \\
& $\%$ & 14.6 & 39.6 & 26.0 & 20.8 \\
Direct & No & 5 & 28 & 18 & 3 \\
& $\%$ & 9.3 & 51.9 & 33.3 & 5.6 \\
Adapt & No & 4 & 4 & 4 & 4 \\
& $\%$ & 23.6 & 23.6 & 23.6 & 29.4 \\
Ignore & No & 9 & 9 & 12 & 6 \\
& $\%$ & 25.0 & 25 & 33.3 & 16.7 \\
Total & No & 25 & 60 & 46 & 24 \\
& $\%$ & 100.0 & 100.0 & 100.0 & 100.0 \\
\hline
\end{tabular}

Table 7. Result of multiple regression.

\begin{tabular}{cccccc}
\hline Variable & M/R & $\mathbf{R}^{2}$ & Df & F & P \\
\hline Sextype & 0.38 & 0.14 & 3 & 0.77 & 0.89 \\
\hline
\end{tabular}

androgynous or near masculine accounts for " 0.38 " of the variation in responding and coping to stress $(\mathrm{F}=0.77, \mathrm{P}<0.05)$.

\section{Discussion}

It was hypothesized that firstly, androgynous person would respond to the stressful events rationally, evaluate them positively and cope with them directly. Secondly, sextyped person would respond to the stressful events negatively and cope with them indirectly. Thirdly, the feminine sextyped may be worse than the masculine sextype with respect to responding to coping with stress. Several researches proved that [4] these hypotheses not and cope directly confirmed. The ones who positively respond to stress were those who showed feminine sextype traits, followed by androgynous then masculine sextyped and lastly the near masculine. Actually, the undifferentiated type in this study not found. This can attributed to the fact that the sample was composed of adult secondary school teachers. It is obvious that they are well developed and their options towards life events formed. The undifferentiated type usual more common among adolescents [5].

Responding to and coping with in many needs not follow a consistent manner i.e. positive response will always followed by direct coping strategies.

It understood that in many situations an individual's conceptualization of something might differ from his/her actual behavior. As one can observe in Table 5 the androgynous persons respond to the stressful events sometimes as stress, but they came second to the near masculine group in adapting with these events. The only group who never respond to stressful event were the masculine 
sextyped but when considering their coping strategies as a group they ignored the stressful events. the fact that sextyped male experiences less stress may be interpreted as reluctance by masculine male to self-disclose; he may experience as many stressful life events as others, he may be less likely to admit that the events are indeed stressful [6]. Among the four groups the androgynous and feminine sextyped represented the great proportion of the young age categories from 30 years and less ( $45 \%$ androgynous, $36 \%$ are feminine sextyped). A positive response and direct coping strategies held by feminine sextype and androgynous, $56 \%$ and $27 \%$ respectively for the responses. Moreover, for coping with death of relative there were a significant differences $\mathrm{x}^{2}=16.63, \mathrm{df}=9, \mathrm{P}<0.05$. It can be noticed that feminine sextyped and androgynous do respond and cope directly, followed by the masculine sextype and the near masculine.

Engaging in along variety of interpersonal behavior may expose the androgynous persons to more stressors and cause them to experience more internal stress response [7]. Androgynous person comes first and followed by feminine and masculine groups when adapted with the stress, they represented $33.3 \%$, $25 \%$ and $25 \%$ respectively. $60 \%$ of the females are feminine sextyped while males who are traditionally sextype and those who are androgynous were $29.9 \%$ and $29.9 \%$ respectively.

Females are usually traditionally sextype and they tend to follow their prescribed position in their given society, so they restricted themselves to their traditional roles [5]. We believe that female evaluates the stressful events and weights them as potentially dangerous and one has be carefully attended to, while males we think are responsible yet they tend to underestimate the danger of stressful experiences. Indeed the sextype male may consider complaining masculine type [8].

Socialization procedures play a crucial role in determining one's attitudes and as the result of the different "Mental programs" that each individual carries and by which his/her behaviors determined. These mental programs are a product of early childhood reinforced in later life by socialization and life experiences in a cultural group or society [9].

Females in Sudan exposed to a limited and stable environmental setting i.e. girls surround by family's members, tend to limit colleagues and friends. Males also have these types of exposition but their colleagues and friends are different. They face great challenges and many activities in different life aspects, social, economic, political, sport among others, they view a multiple settings. Boys are from the beginning prepared to hold the responsibilities of themselves, their siblings, home's needs, and to participate with his parents to formalize and implement the above demands and achieve satisfactory deeds. Happy life and cooperative family members evidence this. Boys brought up to play the dominant role in the family; installation of new home is mainly a responsibility of male's decision. Despite of embodied female role in family affairs. It seems that, it is the male's permission for establishing a home life whether these males are fathers, 
brothers, husbands, or sons. Females themselves accept this dramatic setting, they may have a great role and responsibilities in establishing family, home, children, people, and nation, but abandoned their efforts, and give them satisfactory to their co-existence males.

Researchers into social stress, regardless of their orientations, give serious thought and consideration to the family. It unquestionable the institutional sphere (more than any other factors) that engages the stress process in intense and varied ways. This can attributed to many reasons. These factors are as follows:

Family is the place where relationship formed at birth and continued through the entire life.

The arena where crucial needs of the earliest stages of life, and at last stage were satisfied, people depend on family for their biological needs.

The family then is crucial to stress because it is crucial to social and emotional life itself. Different socializing agents encourage male to confront situations of difficulties bravely.

Conversely, females can express their fear and worry frankly [10]. Consequently, females are sensitive to any stressful events that may threaten their existence, which are determined and connected with the stability of the family as a minor sector and society as a major one [11]. So, their reactions to stressful events are direct oriented style to eliminate or hinder the consequences of these stressful events. This may be attributed to the fear that expressed by females in such a direct coping. In spite of the education and work opportunities that recently maintained however, we believe that the impact of the socialization style of the Sudanese family, females may suffer a lot when one of these events occurs, because usually they are not equipped enough with elements that help them to encompass these troubles. However, the emotional, cognitive, and social elements were not quietly satisfied. Educated, workers women treated similarly to their counterpart women, in certain situational settings.

Males on the other hand, have socialized to face and confront the difficulties without complaining, so they do not evaluate the stressful events as danger or much effective. Men generally are reluctant to show their real feelings, which they believe, may devaluate their social position. Then they tend to be passive and they do not worry about stressful events.

Androgynous, is the one who possesses good quality of both feminine and masculine traits. It seems that, this may solve the problem of restricting and coping with troubles. The position of androgynous comes second, similarly if feminine sextyped is dominant androgynous comes second [12]. This may justify the finding that we have. When feminine sextyped responded positively and coped directly, it followed by androgynous and when masculine sextyped coped indirectly it followed by androgynous (55.9\% and $26.6 \%$ respectively) and (33.3\% and $25 \%$ respectively). Sextyped individual appears to be restricted in their choice every day behavior, androgynous individual appears to be open in 
their choice.

Another hypothesis state that persons on the young age respond positively and cope directly, inversely to the middle and old ones. Consequently, psychosomatic diseases prevail more among those who respond to stress negatively and cope indirectly. This hypothesis confirmed by our results, as age increases responding to stress becomes negative and coping with it becomes indirectly takled. There were significant differences among four categories of Bem sextype concerning the age $\left(x^{2}=16.53, \mathrm{df}=6, \mathrm{P}<0.01\right)$. The age group of 30 years and less consists of $45.9 \%$ of feminine sextyped 36.11 percentage are androgynous, 9.22\% are near masculine and $8.33 \%$ are masculine sextyped, Table 4 . The age groups from 31 - 39 years, feminine sextyped and androgynous represented $34 \%$ and $23.9 \%$ respectively. Masculine and near masculine represented $20 \%$ and $20 \%$ respectively. The psychosomatic diseases prevail more among feminine sextyped $42.9 \%$ followed by androgynous $31.9 \%$ and then masculine sextyped $16.5 \%$ and lastly the near masculine $8.8 \%$.

One can notice that most young age from 30 - 39 years are feminine sextyped and androgynous and the categories who responded and coped positively and directly are feminine sextype and androgynous. That means as the age increases responding and coping with stress become less positive and less direct. Nevertheless, we do not know if it is due to the age or the sextyped factors. Actually, the age factor correlates positively with responding and coping with stress. Those whose age is 40 years were androgynous and masculine sextyped. They represent $37 \%$ and $31 \%$ respectively. As age increases the rigidity decreases and flexibility compensates it [13]. Moreover, the stressful events that showed the significant relations are death of spouse, death of relative, death of friends, marriage, pregnancy, retirement, sex difficulties, habit change and change of responsibility at work. Furthermore, Sudanese socialization procedures put great emphasis on the social relations, particularly the relative and familial ones. Thus, the experiences that threaten these bounds usually have deepest effects and negative impacts on the individuals.

Generally, personality factors, belief system, motivational states and situational variables, all of which determine the manner in which the individual perceives the situation and thus responds. Sextyped is one of the personality attitudes acquired as others attitudes. However, sextype and sex role acquired through direct instruction either by identification or by adapting social roles. These attitudes are continuously open to modification and change according to the person's experience. Furthermore, learning and modification of attitudes have their origins in interaction with others, directly or indirectly through movies, advertisement, book, or T.V. [14]. Moreover, acquiring and modifying attitudes is a dynamic process. The individuals confronted with expectations, at the same time they are struggling to increase their competence in dealing with the environment by seeking a helpful attitude.

The androgynous model-as mentioned earlier-eliminates the sex stereotype, 
prevents the gender discrimination. Furthermore, from early upbringing it is important to consider this concept, and reared the children according to it.

\section{Conclusion and Recommendations}

\subsection{Conclusion}

The objectives of this investigation are many. Identifying the role of sextyped (male/female, androgynous, and undifferentiated) traits in facing some of stressful life events, and its coping strategies is the first. Secondly, trying to emphasize the importance of converging femininity with masculinity traits in order to become androgynous. Thirdly, contributing to the area of sextyped, and mental health in Sudan by utilizing knowledge that found in the literature. Fourthly, justifying some of the differences if any, between androgynous and sextyped person in using certain coping strategies. Fifthly, suggesting certain preventive socializing procedures consisting androgynous concept. The respondents were $155 \mathrm{sec}-$ ondary school teachers, their ages range between 25 to 40 years, the average age being 32 years. The sample randomly selected from the group of teachers in Khartoum, Omdurman, and Khartoum North (Sudan capital). The principal tool used was a questionnaire. It consists of three parts. The first is Bem sex role inventory for measuring androgyny. The second part consists of items from the social readjustment rating scale for stress measure and the third part consists of some of the psychosomatic diseases. The main results are Feminine sextyped and then the androgynous who positively regarded the stressful experience as stress and consequently they directly cope with these events. Masculine sextyped and near masculine respond negatively and cope indirectly. Psychosomatic diseases prevail among feminine sextype and androgynous. Feminine sextype and androgynous represent the majority of the young age group (30 and less to 39 years). As age increases responding and coping with stress become less positive and indirect.

\subsection{Recommendations}

Different socializing institution has to utilize the humanistic experiences for the individuals without discrimination on any basis. To work for abolishing the attitudes that restrict human is positive behavior, and stereotyped style that hinders the beneficial effects of what is available on the world around people.

To make use of the cultural values and religious heritage which emphasize the equality and justice among individuals. Thus, this will give opportunity for all people to gain skills and abilities in accordance to his/her potentialities.

For further studies, we recommend studies on the area of psychological androgyny with large sample, among different groups by using other additional instrumental measures of stress and coping strategies comprehensively. We have to put in mind that the processes of change of attitudes were continuous and their consequences appear eventually. 


\section{Conflicts of Interest}

The author declares no conflicts of interest.

\section{References}

[1] Bem Sandra, L. and Lewis Steven, A. (1975) Sex Role Adaptability: One Consequence of Psychological Androgyny. Journal of Personality and Special Psychology, 31, 634-643. https://doi.org/10.1037/h0077098

[2] Vafaei, A., et al. (2014) The Validity of the 12-Item Bem Sex Role Inventory in Older Spanish Population: An Examination of the Androgyny Model. Archives of Gerontology and Geriatrics, 59, 257-263. https://doi.org/10.1016/j.archger.2014.05.012

[3] Appley, M.H. and Trumbul, R. (1967) Psychological Stress. Meredith Publishing Company, New York.

[4] Kaplan, A.G. and Bean, J.P. (1976) Beyond Sex-Role Stereotypes: Reading towards a Psychology of Androgyny. Little, Browns and Company, New York.

[5] Bakhet, S.M. (2021) Psychological Androgyny and Sex Type Person among Sudanese University Students. International Journal for Indian Psychology, 9, 1424-1430.

[6] Harris, M.B. and Voorhees, S.D. (1981) Sex-Role Stereotypes and Televised Males Emotion. Psychological Reports, 48, 826. https://doi.org/10.2466/pr0.1981.48.3.826

[7] Lesters, D. and Brower, E.R. (1981) Stress and Job Satisfaction in a Sample of Pediatric Intensive Care Nurses. Psychological Reports, 48, 738. https://doi.org/10.2466/pr0.1981.48.3.738

[8] Rehm, L. (1981) Behaviour Therapy for Depression. Harcourt Brace Jovanovich, New York.

[9] Kanfer, F.H. and Arnold, P. (1980) Boldstin, Helping People Change. Pergamon Press, New York.

[10] Rathus, S.A. and Nevid, J. (1980) Adjustment and Growth, the Challenges of Life. Holt, Rinehant and Winston, New York.

[11] Kilbride, J.M. and Napali, V. (1984) Adjustment and Growth in a Changing World. West-Publishing Company, St Paul.

[12] Craic, J.R. and Metze (1975) Leroyp Methods of Psychological Research. W. B. Swnders Company, Philadelphia.

[13] Moos, R.H. and Holahan, C.J. (1987) Personal and Contextual Determinants of Coping Strategies. Journal of Personality and Social Psychology, 52, 946-955. https://doi.org/10.1037/0022-3514.52.5.946

[14] Schaffer, K.F. (1980) Sex Role Issues in Mental Health. Wesley Publishing Company, Reading. 